\title{
Lecturer's Working Environment and Teaching Competence in Selected Agricultural Colleges in Vietnam
}

\author{
Duong Thai $\mathrm{Le}^{1} \&$ Cuong Hung Pham ${ }^{2}$ \\ ${ }^{1}$ Southern College for Engineering and Agriculture, Vietnam \\ ${ }^{2}$ Foreign Trade University, Ho Chi Minh City Campus, Vietnam \\ Correspondence: Cuong Hung Pham, Foreign Trade University, Ho Chi Minh City Campus Binh Thanh District, Ho \\ Chi Minh City, Vietnam. \\ Received: July 15, 2016 \\ Accepted: August 11, 2016 \\ Online Published: October 8, 2016 \\ doi:10.5430/ijfr.v7n5p56 \\ URL: http://dx.doi.org/10.5430/ijfr.v7n5p56
}

\begin{abstract}
The paper entitled Lecturer's working environment and teaching competence in selected agricultural colleges in Vietnam conducted during the period from October 2013 to March 2016. This section demonstrates how the target and objectives of the study have been achieved. Moreover, answers to the research questions are provided. The study was conducted in 12 colleges, under the Ministry of Agriculture and Rural Development, with agricultural major in Vietnam, the total sample of 300 leaders, managing officers and lecturers. Data analysis using SPSS 16.0 software.

Defined seven criteria for assessinglecturer's teaching competence in agricultural colleges in Vietnam consist of: i) Professional competence and broad understanding; ii) Competence on understanding students during teaching process; iii) Competence on lesson composing; iv) Teaching organizing competence; v) Evaluating and criticizing competence; vi) Competence for communicating, negotiating and making decisions; and vii) Competence for learning and self-developing. With significance level of $5 \%$, The factors of working environment are listed in descending order of their influence on the development of lecturer's teaching competence as follows: i) Working conditions; ii) Lecturer's relationships; iii) Study and promotion opportunities of lecturers; iv) Working pressure and managing environment; v) Students. Within these factors, the factor working conditions is dependent on financial investment, whereas others depend less on financial investment but more on time investment and support from the leaders and staff of lecturers to improve the cultural-psychological environment; at the same time it is necessary for colleges to build reasonable schemes and policies towards lecturers. Results of this research are important and reliable scientific materials, on which colleges can apply to enhance the lecturer's working environment, contributing to helping them develop their teaching competence and improving the quality of teaching. This research also serves as the scientific foundation for future research in relevant fields.
\end{abstract}

Keywords: lecturer's working environment, teaching competence, agricultural colleges, Vietnam

\section{Introduction}

Improving education quality to meet the needs of society is the most important goals of university education and vocational education. A unified set of solutions is necessary to accomplish this goal. "It is not easy to solve the problem of higher education quality. There must be thorough changes in both training system and process. However, it does not mean that we should ignore it. In my opinion, there are 3 crucial factors that we should take into consideration including people, infrastructure/equipment used for training and international integration competence". (Dr. Nguyen Dinh Luan - Principal of Hanoi University: 2013). "To develop higher education quality, I think we should focus on 3 essential aspects which are curriculums, teachers and vocational skills. Specifically, considering curriculum, it is necessary to guide the students on how to apply academic knowledge into various practical situations in the economy where the students are living and working. Teachers must be responsible for teaching quality. For instance, in University of London, teachers must be native English speakers to remain the British accent. For vocational skills, they must be flexible and developing. Not only should the students be taught on what they have known, but they should also be taught to meet the society needs. In particular, when building the curriculum framework, new society demands must be used to restructure the curriculum in a more practical ways (Prof Graeme John Davies - used to be principal of University of Liverpool, University of Glasgow and University of London; now principal of British Vietnam University: 2013). Therefore, in general, education quality depends on (1) people: 
teachers, administrative staff; (2) university: infrastructure, equipment, programs and curriculums, working environment; (3) international integration competence. In which, from both academic and practical education, it can be stated that: "The educators are the most important factor in assure education quality" (Article 15, Vietnam Education Law: 2005). The teaching competence of lecturers is the most important factor affecting the quality of teaching and training.

There have been many researches about the effects of work environment on work quality, effectiveness and productivity of employees in companies, factories or schools. Work motivation and satisfaction level of teachers has also been studied before. Nonetheless, the topic of the relationship between university/college work environment and the development of teachers is still new with not many studies.

\section{Literature Review}

Lecturer competence, was synthesized and given details by Thematic Working Group 'Lecturer Professional Development' of European Commission (2013) include:

Knowledge and understanding: Subject matter knowledge; Pedagogical content knowledge, implying deep knowledge about content and structure of subject matter; Pedagogical knowledge (knowledge of teaching and learning processes); Curricular knowledge (knowledge of subject curricula - e.g. the planned and guided learning of subject-specific contents); Educational sciences foundations (intercultural, historical, philosophical, psychological, sociological knowledge); Contextual, institutional, organizational aspects of educational policies; Issues of inclusion and diversity; Effective use of technologies in learning; Developmental psychology; Group processes and dynamics, learning theories, motivational issues; Evaluation and assessment processes and methods;

Skills: Planning, managing and coordinating teaching; Using teaching materials and technologies; Managing students and groups; Monitoring, adapting and assessing teaching/learning objectives and processes; Collecting, analysing, interpreting evidence and data (school learning outcomes, external assessments results) for professional decisions and teaching/learning improvement; Using, developing and creating research knowledge to inform practices; Collaborating with colleagues, parents and social services, Negotiation skills (social and political interactions with multiple educational stakeholders, actors and contexts); Reflective, metacognitive, interpersonal skills for learning individually and in professional communities; Adapting to educational contexts characterised by multi-level dynamics with cross-influences (from the macro level of government policies to the meso level of school contexts, and the micro level of classroom and student dynamics);

Dispositions of beliefs, attitudes, values, commitment: Epistemological awareness (issues concerning features and historical development of subject area and its status, as related to other subject areas), teaching skills through content, transferable skills; Dispositions to change, flexibility, ongoing learning and professional improvement, including study and research; Commitment to promoting the learning of all students; Dispositions to promote students' democratic attitudes and practices (including appreciation of diversity and multiculturality); Critical attitudes to one's own teaching (examining, discussing, questioning practices); Dispositions to team-working, collaboration and networking; Sense of self-efficacy.

Neal Van Alfen, J. Scott Angle et al. (2007) identified four factors that must be addressed in order to develop university teaching staff: (1) building knowledge base for lecturers; (2) fostering teaching skills of lecturers; (3) enhancing lecturers' knowledge on researching; and (4) educational paradigm shift from teaching theory into practice.

Thus, the competence of lecturers in general is a concept that has broad connotations relating to lecturers in tertiary education system. According to Nguyen Huu Lam (2009)aside from ethical and political standards, a good lecturer should meet the following requirements: (1) high professional competence to capture the latest developments in academic as well as in their professional practice; (2) teaching capability that complies with their expertise; and (3) in-depth researching competence in their expertise. (Figure 3: Competence of a typical university lecturer). These three elements are combined to form the competence of a lecturer which show a dialectical relationship with each other. However, this study only refers to the competence of teaching. 


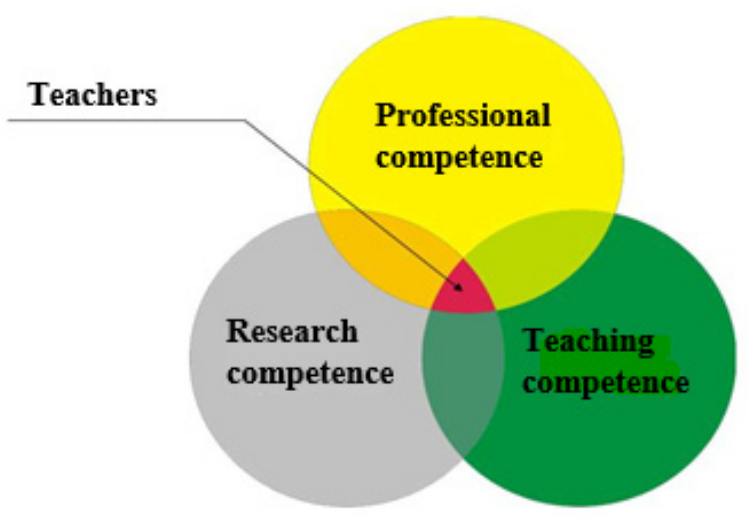

Figure 1. Competence of a university lecturer

Teaching competence. Distinguishing between teaching competences and lecturer competences, OECD (2009). Teaching competences are focused on the role of the lecturer in the classroom, directly linked with the 'craft' of teaching - with professional knowledge and skills mobilised for action, Hagger \& McIntyre (2006). Lecturer competences imply a wider, systemic view of lecturer professionalism, on multiple levels - the individual, the school, the local community, professional networks.

Based on theoretical and research data, this study is built to identify the criteria set of teaching competence of university lecturers at many universities and colleges within agricultural training area as below:

Table 1. Combined criteria on teaching competence

\begin{tabular}{|c|c|}
\hline Criteria & Performance index \\
\hline $\begin{array}{l}\text { Professional } \\
\text { competence and broad } \\
\text { understanding }\end{array}$ & $\begin{array}{l}\text { - Always master the practical knowledge and skills that is of lecturers' } \\
\text { expertise. } \\
\text { - Have the teaching competence for multiple subjects within a major. } \\
\text { - Have broad understanding besides expertise. }\end{array}$ \\
\hline $\begin{array}{l}\text { Competence on } \\
\text { understanding students } \\
\text { during teaching } \\
\text { process }\end{array}$ & $\begin{array}{l}\text { - Knowing students' level of learning, discovering and developing the } \\
\text { competence of students } \\
\text { - Always try to understand the advantages and disadvantages of students } \\
\text { during the lesson. } \\
\text { - Proper task delegating to students as per learning level. } \\
\text { - Willing to support students after class. } \\
\text { - Always put students in lecturers' shoes. }\end{array}$ \\
\hline $\begin{array}{l}\text { Competence on lesson } \\
\text { composing }\end{array}$ & $\begin{array}{l}\text { - Lecturers are well aware of building knowledge transferring system and } \\
\text { always refer to practical issues. } \\
\text { - Identify precisely learning materials for students. } \\
\text { - Apply scientific research outcomes on lectures. } \\
\text { - Fully prepare the facilities and tools to meet the lesson requirements. } \\
\text { - Have thorough planning skill for every lecture. }\end{array}$ \\
\hline
\end{tabular}




\begin{tabular}{ll}
\hline & - Allocate knowledge properly for every lecture. \\
& - Have organizing skill which can help appeal students towards class activities. \\
& - Apply appropriate teaching methods. \\
Teaching organizing & - Make effective use of teaching tools. \\
competence & - Conduct experiments/practical case study/seminars for students. \\
& - Utilize teaching approaches that encourage students to work and think \\
\hline & - independently. \\
\hline $\begin{array}{l}\text { Evaluating and } \\
\text { criticizing competence }\end{array}$ & - Diversify testing measures - assessing awareness process and skill \\
& - Precisely, transparently and fairly evaluate testing papers of students. \\
\hline & - Be able to coherently express in teaching and communicating. \\
$\begin{array}{l}\text { Competence for } \\
\text { communicating, }\end{array}$ & - Lectures are led towards personality development for students. \\
negotiating and making \\
decisions
\end{tabular}

Professional competence and broad understanding (1): this is the utmost important criterion which is the mandatory "hardware" component. This can be explained as for comprehensive personality development for students, lecturers must have knowledge and practical skills that are of teaching expertise. These criteria have already been thoroughly provided for lecturers at higher degree (much higher than that of students as commonly agreed in Vietnamese idioms). At the same time, lecturers should continue to learn, update these criteria by collecting knowledge during the process of professional practical activities.

The competence on understanding students during class (2): are considered key indicators of pedagogical competence and are prerequisites for successful teaching activities. Lecturers should understand the circumstances of the students to take appropriate measures to influence students and to help them obtain the best development. Competence is defined as: predicting the level of difficulty and advantages of students when learning new lessons; understanding clearly students' degree; measuring the level of students' understanding; understanding the personality characteristics of students (personality, orientation, strengths...); having the capability to analyze, synthesize, build psychological portrait of students, observe and determine students' feedbacks; memorize each traits of students...

Competence for lecture preparation (3): is regarded as an integral part of pedagogical competence. On the basis of training objectives of each university, programs and programs target (lecturers must master through pedagogical activities of the school and the faculty), the circumstances and the conditions of the school facilities and the knowledge of student subjects, lecturers should: identify basic knowledge and skills in lectures; determine the relationship between knowledge and skills in the lectures; identify and mobilize the knowledge and skills related to the lectures; contact and apply lectures to practical situations; plan to use teaching methods appropriate with the content of the lectures; prepare the tools and facilities (materials, models, machinery, equipment, tools, raw materials, seedlings, fieldtrip ...) in order to meet with teaching and learning requirements; plan students' activities in class; plan teaching timeline, estimate in-class situations that may arise.

Competence on teaching organization (4): is considered the most important criterion of teaching competence. This realizes and produces the outcomes for teaching progress. Teaching process involves lecturer's activities (teaching activities) and student's activities (learning activities) which complies with modern education viewpoint that centralize the role of students. Meanwhile, lecturers provide guidelines and communications to transfer knowledge by means of 
active and creative learing absortion of students. Teaching competence comprises the following skills: Organizing learning activities for students; expressing teaching content with practical guidelines; applying appropriate teaching methods, encouraging independence and creativity from students; use modern teaching facilities; perform experiments and case studies; cover and manage classroom activities, organize and mobilize all students to bes engaged in the learning activities, pay attention to particular students; allocate reasonable teaching schedule; resolve situations arising during class; impose multiple test questions for class assignments; provide students with clear communication that is rich in expression, accurate, articulated, coherent, expressive and convincing.

Competence for controlling and evaluation (5): Is the competence that enables lecturers to know the extent of achieving the objectives of lectures/programs and training goals. At the same time, they are also the feedback signals from student for the results/ performance efficiency of the competence (1), (2), (3), (4) as the basis for lecturers to gain experience to develop their teaching competence. This competence includes the following points: Lecturers always give right questions for students; diversify the forms of examination/evaluation process for assessing knowledge and training skills of students which matches the object, nature and objectives of the lecture/program; evaluate the students' test clear, accurate and fair.

Competence for communication, negotiation and making decisions (6): is a fundamental component of pedagogical activity. Not only do lecturers communicate with students during school hours, but they also spend hours of extracurricular activities and other activities in and outside the school, during which there will be practical problems (pedagogical situations) to be solved. In such case, lecturers must always put themselves in the position of students and parents; analyze and correct situations that are identified; find or suggest the best solution to resolve the situation; communicate by using multiple verbal and non-verbal tools for appropriate circumstances; know how to cleverly integrate and orientate personality development for students, help students with critical analysis and formation of personal reasons; seek knowledge for personal targets; enable students to form the passion for their subjects and discipline, and make them desire to contribute their knowledge to social service. To develop this competence, lecturers must be equipped with the basic platform for pedagogical, student psychology, moral norms and stipulations; have the motivation and attitude to work, have a favorable working environment, and be offered experience and support from colleagues, especially the active participation and initiatives from students.

Competence for learning and self improvement (7): This competence does not affect directly teaching activities of the faculty, but it is fundamental to the development of all combined teaching competencies of lecturers. It is the nature of the competence that can create unique characteristics of each person. If working environment (physical and mental) is favorable, it will promote development of the students. This competence as for lecturers includes self studying, participation in learning courses to improve professional qualifications, teaching professions; being aware of progression (self-learning and acquire contributive comments of colleagues during teaching activities); being able to contribute to building class lessons.

Working environment. People are happiest and most productive when they work in an environment that suits them, M Coll School of Business (2011).

As suggested by Bui Huy Khien (2013) environment is everything surrounding us, enabling us to live, to work and to develop. Working environment is a combination of human factors and the physical means to help people work with satisfied productivity, quality and efficiency. Working environment is perceived as in two aspects: the physical and the non-physical. Physical environment includes: office layout which is neat, reasonable arranged, and favorable to facilitate the implementation of common and individual tasks. Facilities of the workplace must ensure the requirements of the job with the following conditions: rational office area, unpolluted working space, decent equipment and machinery for work and provided with enough trees and air conditioning... Cultural and psychological environment: is defined as a system of values formed during the operations in the workplace that create trust, attitude value of the employees and affect the way work is carried out in the office and its performance in practice. Cultural environment psychology is formed within the relationship between cadres and civil servants during their work, inclusive of codes of conduct, etiquettes of administrative contact, methods to resolve the conflict within the organization, the system of regulation and the implementation of the regulation, leadership style, psychological climate in the organization and also the organization's traditions...

Whereas, towards the suggestions of Ly Thi Kim Binh (2011) working environment is a term with broad meaning which covers every relevant things. It directly affect the operations, development and improvement of each employee (including internal and external environment). Working environment in employees' respect (to be assessed as internal environment), includes facilities, working spirit, company policies, the relationship between managers and employees, and among employees themselves... in a certain company, organization or unit. A good working environment is 
considered of grand importance that has significant effects on the development of cadres and civil servants as well as determining the quality and performance of the companies, organizations and units...

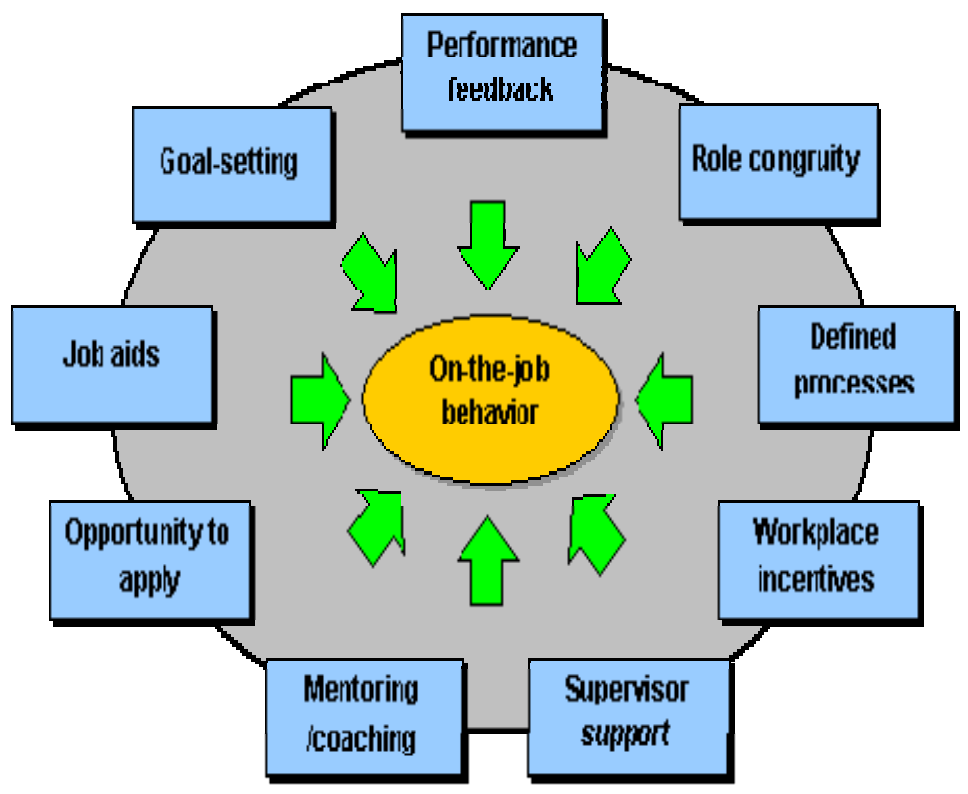

Figure 2. Workplace factors affecting employee performance

A brief explanation of each factor is: (1) Goal-setting: Employees are involved in setting meaningful goals and performance measures for their work, this can be done informally between the employee and their immediate supervisor or as part of an organization's formal performance management process, the key here is that each employee is actively engaged in the goal-setting process and takes ownership of the final agreed goals and measures; (2) Performance feedback: Information on how the employee is performing is fed back regularly to employees, this consists of both positive feedback on what the employee is doing right as well as feedback on what requires improvement, the feedback is objective and delivered with the appropriate interpersonal and conflict resolution skills and can be a mix of both informal feedback and feedback delivered as part of a formal performance management cycle; (3) Role congruity: The role that the employee is required to perform is consistent with their expectations on joining the organization and any subsequent training, the organization's role expectations are typically reflected in formal documents, such as Job Descriptions and Role Specifications, these expectations are consistent with tasks allocated by the employee's immediate supervisor; (4) Defined processes: The organization constrains the variability of how work is actually performed through documenting processes and communicating such expectations to employees, the organization verifies on a regular or random basis that the work is actually performed in the way required; (5) Workplace incentives: The organization has determined what motivates its employees and has set up formal and informal structures for rewarding employees that behave in the way required, rewards may consist of a mix of internal rewards, such as challenging assignments, and external rewards, such as higher compensation and peer recognition; (6) Supervisor support: Immediate supervisors act as advocates for employees, gathering and distributing the resources needed by employees in order for them to be able to do a good job and providing positive encouragement for a job well done, supervisors display the interpersonal skills required to engage employees and enhance their self-confidence; (7) Mentoring/coaching: Skilled and respected people are available to employees to help them perform better in their current role and to assist them develop further into a future role, mentors and coaches may be internal to an organization or external. Either way, they possess the necessary facilitation skills to assist employees develop and apply new skills; (8) Opportunity to apply: Time and material resources are available to employees, enabling them to perform to the best of their ability, individual workloads and organizational systems and processes do not hinder employees from applying established skills or from practicing newly learned skills; (9) Job aids: The work environment is set up so that templates, guides, models, checklists and other such workplace aids are readily available to help minimize error rates and customer dissatisfaction. Each of these nine factors is significant in its own right. Taken together, they form a powerful coalition for maximizing the motivation and productivity of the employees. 


\section{Conceptual Framework}

The research paradigm is presented in Figure 3. This guided the researcher in showing the relationship between lecturer's working environment and teaching competence.

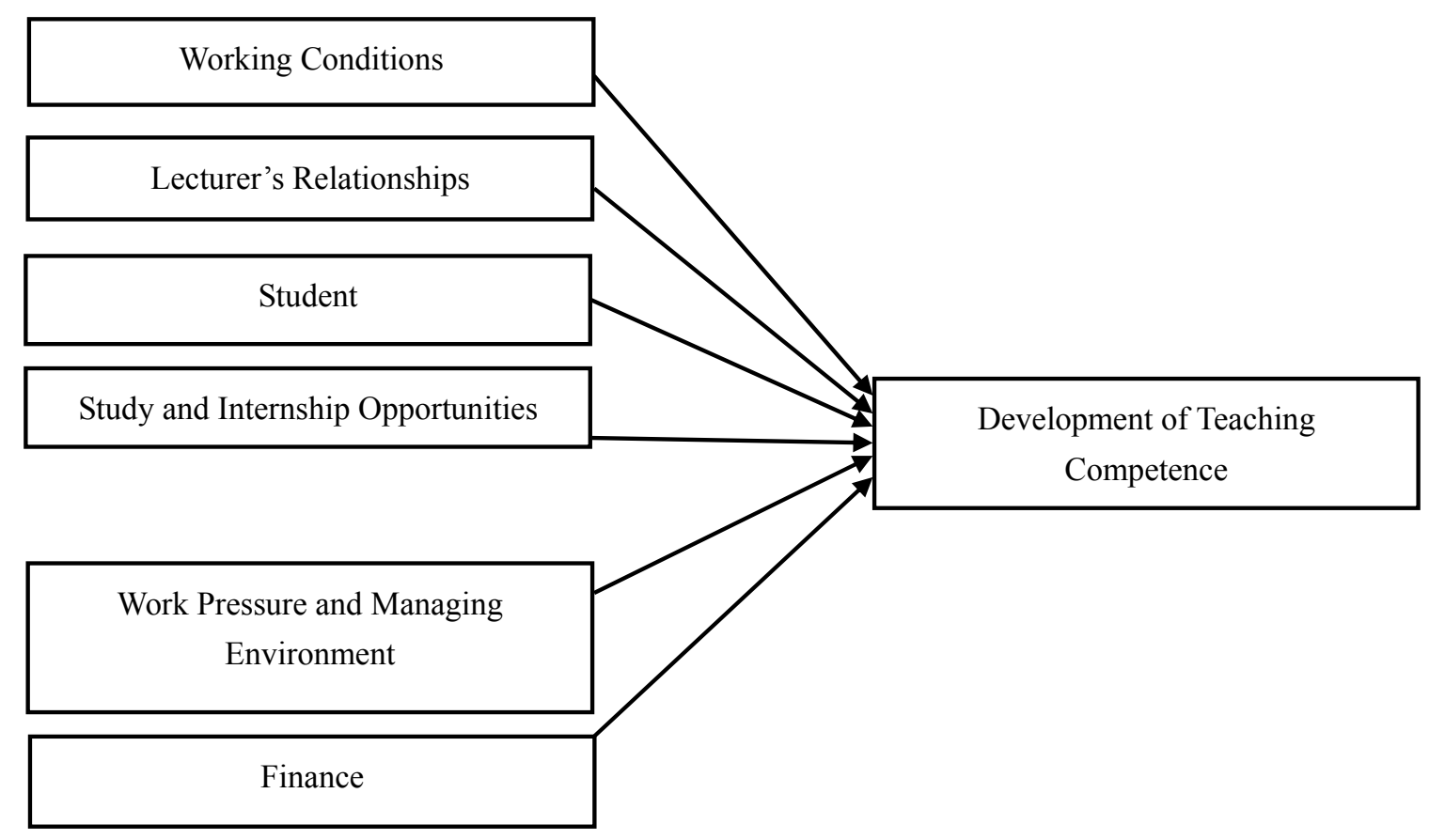

Figure 3. Paradigm of research

Teaching competence: Teaching competences are complex combinations of knowledge, skills, understanding, values and attitudes, leading to effective action in situation. The criteria of teaching competence.

Lecturer's working environment: The working environment of lecturers is a combination of human factors and physical means to help lecturers gain productivity, quality and efficiency. Working environment of lecturers includes: working conditions; the relationship of the lecturers; college student; learning and advancement opportunities; pressure of work and environment management and financial issues.

Working conditions: are parts of physical environment including: working equipment for lecturers: office space, tables/chairs, computers, stationery; safety workwear...; Teaching equipments: factory/field trip/experiments, laboratory, models and instruments; equipments and teaching aids: classrooms and classroom equipment (tables, chairs, lamps, fans, tables ...), projector, method room; library, books, professional documents, references and other materials (hard copy and electronic copy); information systems: internet connection, software on training management, school website; infrastructure for culture/arts, physical education/sport, recreations, entertainment ...; the arrangement of functional areas in the school: teaching areas/academic and administrative areas, area for practice/laboratory, physical activity zones, parks, trees ...

Lecturer's relationships: are reflected by the cultural-psychological environment, surrounding working atmosphere, including lecturers' relationships with other members of the faculty/department; relationships with faculty managers and function rooms; relationships with school leaders; relationships in socio-political organizations; relations with other units/business/manufacturing facility specialized in such field; relationships with lecturers and other school employees; relationships with students before, during and after teaching and also with alumni.

Students: are involved in the cultural environment which is assessed by the aspects of affecting and feedbacking, students are the object of the implementation competence of teaching faculty which includes: knowledge, skills and attitudes of students while learning; the level of response, interaction, self-consciousness and activeness of students before, during and after teaching; the number of students in a classroom. 
Study and internship opportunities: is part of the cultural-psychological environment, inclusive of advanced academic qualifications; learning/training courses in teaching methods; thematic seminars, information updates for specialized profession domestically and internationally; field trips/annual internship at businesses or manufacturing firms under a specialized field and promotion opportunities.

Work pressure and managing environment: is the physical and cultural-psychological environment which includes: objectives and training programs; standard for teaching duration within a schoolyear and teaching schedule (training intensity); rules and regulations on teaching operations; the regime for supplies, materials and resources for teaching/practice/internship; respect and independence in their work; the right to participate in planning teaching activities for the faculty and university; being assessed and fully acknowledged for completed work in a fair manner and democracy; stable work delegation; higher engagement with the faculty; tactful discipline and resolution from higher management; the support from their supervisors to solve personal problems. Moreover, schools should have policies to attract and support talent pool and take into account the location, position and tradition of the school.

Finance: is the cultural-psychological environment. This comprises salaries, bonuses and additional income; insurance policies and pensions; academic and training support regime,; unemployment and unemployment allowances; subsidies for family and personal difficulties; subsidies for periodically health check and travelling offer; and other supports for traditional festivals, funerals ...

\section{Methods of Research}

The objective of the study is to identify and evaluate influence of working environment factors on teaching competence development of lecturers in agricultural colleges in Vietnam. The Independent Variables include (1) Working conditions, (2) Lecturer's relationships, (3) Student,(4) Study and internship opportunities, (5) Work pressure and managing environment, (6) Finance. And Dependent Variable is development of teaching competence. Based on that, the approach of research topics is to engage, collect and analyze data with the help of software such as Microsoft Office, SPSS. The research methodologies used in the research are listed below:

Within this study, the qualitative research approach is applied to help provide references to various theoretical bases such as: the theory on working motivation, working environment, and the teaching competence of lecturers. Simultaneously, domestic and international materials are also comprehensively assessed with a view to exploring, adjusting and adding extra observation variables to measure the concepts (factors) affecting the teaching competence of lecturers. This approach is conducted though an interview session with experts and group discussion. The mentioned approach serves as the fundamental for official researches carried out through the quantitative research approach.

The quantitative method includes the process of data collection, data analysis, interpretation, and deliver the study results. Various specific methods are developed for this kind of research based on investigation / survey forms as well as research in controlled conditions (experimental implementation). These specific methods are related to overall sample determination, clearly state investigation strategy, collect and analyze data, present results, give explanation and how to write research appropriate to the research type.

In this study, quantitative research method is implemented by means of direct interviews with lecturers, managers and leaders of agricultural colleges in Vietnam through detailed questionnaires to measure the importance level of elements drawn from qualitative research.

5-level Likert scale is used to measure the value of observed variables. Information collected from questionnaires is used to measure the composition of factors affecting teaching competence development of lecturers.

Population and Sample of the Study. Aforementioned in Chapter 1, there are 28 universities and colleges offering Agriculture - Forestry - Fisheries in Vietnam, among which there are 4 universities and 12 colleges under the management of the Ministry of Agriculture \& Rural Development, and no private institutions having such majors. Therefore, this study shall focus on inspecting these 12 colleges, with the total number of lecturers, managing officers amounting to 1,195 people.

For clearer understanding of the population of the study, the distribution of respondents is presented in Table 2 and 3.

Table 2. The quantity of lecturers and their professional level in 12 colleges under the management of the Ministry of Agriculture \& Rural Development

\begin{tabular}{cccccc}
\hline Total & Female & PhD. & MSc. & BSc. & Others \\
\hline 1195 & 475 & 13 & 639 & 527 & 16 \\
\hline
\end{tabular}


Table 3. The quantity of lecturers in colleges under the management of the Ministry of Agriculture \& Rural Development

\begin{tabular}{|c|c|c|c|}
\hline No. & Name of institution & $\begin{array}{l}\text { Number of } \\
\text { lecturers }\end{array}$ & $\begin{array}{l}\text { Number of samples } \\
\text { being inspected }\end{array}$ \\
\hline 1 & College of Food Industry & 130 & 32 \\
\hline 2 & Fishery College & 96 & 24 \\
\hline 3 & $\begin{array}{l}\text { Northern College for Agriculture and Rural } \\
\text { Development }\end{array}$ & 133 & 33 \\
\hline 4 & North East College for Agriculture and Forestry & 105 & 26 \\
\hline 5 & Northern College for Waterresources & 87 & 22 \\
\hline 6 & Southern Agriculture College & 83 & 21 \\
\hline 7 & Hanoi College of Technology and Economics & 149 & 37 \\
\hline 8 & $\begin{array}{l}\text { Central Region College of Technology-Economics } \\
\text { and Waterresources }\end{array}$ & 60 & 15 \\
\hline 9 & Bao Loc College of Technology and Economics & 98 & 24 \\
\hline 10 & Southern College for Enginerring and Agriculture & 128 & 32 \\
\hline 11 & Rubber Industrial College & 67 & 17 \\
\hline \multirow[t]{2}{*}{12} & College for Economics and Food Technology & 59 & 17 \\
\hline & Total & 1195 & 300 \\
\hline
\end{tabular}

\section{Research Results}

Criteria on teaching competence of lecturer in agricultural colleges. The quantitative data collected from surveys using descriptive statistics on 7 criteria assessing the teaching competence of lecturers is as follows:

Professional competence and broad understanding (NLGD1) presents the average result of $M=4.02$ (Appendix B1).

Table 4. Professional competence and broad understanding

\begin{tabular}{llrrrr}
\hline & & & & \multicolumn{2}{c}{ Cumulative } \\
Valid & 2 & 15 & 5.3 & 5.3 & 5.3 \\
& 34 & 11.9 & 11.9 & 17.2 \\
& 4 & 166 & 58.2 & 58.2 & 75.4 \\
& 5 & 70 & 24.6 & 24.6 & 100.0 \\
& Total & 285 & 100.0 & 100.0 & \\
\hline
\end{tabular}

Source: Results from analyzing the survey data

As can be seen in Table 10, as much as 166 out of 285 people (58.2\%) agreed, and 70 out of 285 people (24.6\%) totally agreed that "Professional competence and broad understanding" is a criterion in assessing the teaching competence of lecturers.

Competence on understanding students during teaching process (NLGD2) presents the average result of $\mathrm{M}=4.3$ 
Table 5. Competence on understanding students during teaching process

\begin{tabular}{llrrrr}
\hline & & & & \multicolumn{2}{c}{ Cumulative } \\
\hline Valid & 2 & 1 & .4 & .4 & .4 \\
& 3 & 27 & 9.5 & 9.5 & 9.8 \\
& 4 & 142 & 49.8 & 49.8 & 59.6 \\
& 115 & 40.4 & 40.4 & 100.0 \\
& Total & 285 & 100.0 & 100.0 & \\
\hline
\end{tabular}

Source: Results from analyzing the survey data

As can be seen in Table 11, there are 142/285 people (49.8\%) choosing to agree, and $115 / 285$ people (40.4\%) choosing to totally agree that "The competence on understanding students during teaching process" is a criterion in assessing the teaching competence of lecturers.

Competence on lesson composing (NLGD3) presents the average result of $\mathrm{M}=3.94$.

Table 6. Competence on lesson composing

\begin{tabular}{llrrrr}
\hline & & & & \multicolumn{2}{c}{ Cumulative } \\
\hline Valid & 2 & 15 & 5.3 & 5.3 & 5.3 \\
& 3 & 55 & 19.3 & 19.3 & 24.6 \\
& 4 & 145 & 50.9 & 50.9 & 75.4 \\
& 5 & 70 & 24.6 & 24.6 & 100.0 \\
& Total & 285 & 100.0 & 100.0 & \\
\hline
\end{tabular}

Source: Results from analyzing the survey data

As illustrated in Table 6, there are $145 / 285$ people (50.9\%) agreeing, and 70/285 people (24.6\%) totally agreeing that the "Competence on lesson composing" is a criterion in assessing the teaching competence of lecturers.

Teaching organizing competence (NLGD4) presents the average result of $\mathrm{M}=3.88$ (Appendix B1).

Table 7. Teaching organizing competence

\begin{tabular}{|c|c|c|c|c|c|}
\hline & & Frequency & Percent & Valid Percent & $\begin{array}{c}\text { Cumulative } \\
\text { Percent }\end{array}$ \\
\hline \multirow[t]{6}{*}{ Valid } & 1 & 2 & .7 & .7 & .7 \\
\hline & 2 & 21 & 7.4 & 7.4 & 8.1 \\
\hline & 3 & 50 & 17.5 & 17.5 & 25.6 \\
\hline & 4 & 148 & 51.9 & 51.9 & 77.5 \\
\hline & 5 & 64 & 22.5 & 22.5 & 100.0 \\
\hline & Total & 285 & 100.0 & 100.0 & \\
\hline
\end{tabular}

Source: Results from analyzing the survey data

According to Table 7, there are $148 / 285$ people (51.9\%) agreeing, and 64/285 people (22.5\%) totally agreeing that the "Competence on teaching organization" is a criterion in assessing the teaching competence of lecturers.

Evaluating and criticizing competence (NLGD5) presents the average result of $\mathrm{M}=4.58$. 
Table 8. Evaluating and criticizing competence

\begin{tabular}{llrrrr}
\hline & & & & \multicolumn{2}{c}{ Cumulative } \\
\hline Valid & 2 & 1 & .4 & .4 & .4 \\
& 3 & 5 & 1.8 & 1.8 & 2.1 \\
& 4 & 106 & 37.2 & 37.2 & 39.3 \\
& 173 & 60.7 & 60.7 & 100.0 \\
& Total & 285 & 100.0 & 100.0 & \\
\hline
\end{tabular}

Source: Results from analyzing the survey data

As in Table 8, there are 106/285 people (37.2\%) agreeing, and $173 / 285$ people $(60.7 \%)$ totally agreeing that the "Evaluating and criticizing competence" is a criterion in assessing the teaching competence of lecturers.

Competence for communicating, negotiating and making decisions (NLGD6) presents the average result of $\mathrm{M}=$ 4.63 .

Table 9. Competence for communicating, negotiating and making decisions

\begin{tabular}{rlrrrr}
\hline & & & & \multicolumn{2}{c}{ Cumulative } \\
\hline Valid & 3 & 3 & 1.1 & 1.1 & 1.1 \\
& 4 & 99 & 34.7 & 34.7 & 35.8 \\
& 5 & 183 & 64.2 & 64.2 & 100.0 \\
& Total & 285 & 100.0 & 100.0 & \\
\hline
\end{tabular}

Source: Results from analyzing the survey data

According to Table 9, there are 99/285 people (34.7\%) agreeing, and $183 / 285$ people (64.2\%) totally agreeing that the "Competence on communicating, negotiating and decision - making" is a criteria in assessing the teaching competence of lecturers.

Competence for learning and self-developing (NLGD7) presents the average result of $M=4.53$.

Table 10. Competence for learning and self-developing

\begin{tabular}{llrrrr}
\hline & & & & \multicolumn{2}{c}{ Cumulative } \\
\hline Valid & 3 & 5 & 1.8 & 1.8 & 1.8 \\
& 4 & 123 & 43.2 & 43.2 & 44.9 \\
& 5 & 157 & 55.1 & 55.1 & 100.0 \\
& Total & 285 & 100.0 & 100.0 & \\
\hline
\end{tabular}

Source: Results from analyzing the survey data

As can be seen in Table 10, there are 123/285 people (43.2\%) agreeing, and 157/285 people (55.1\%) totally agreeing that the "Competence for learning and self-developing" is a criterion in assessing the teaching competence of lecturers.

Testing the scale. The testing results showed that the scale of teaching competence consisting of 7 observation variables (criteria) presents a Cronbach's alpha coefficient of 0.692 which is larger than 0.6. Additionally, all the observation variables show a satisfactory total correlation coefficient $(>0.3)$, hence all these variables are satisfactory to explain the concept Teaching competence of lecturers as illustrated in Table 11. 
Table 11. Cronbach's Alpha coefficients of 7 criteria in assessing the teaching competence of lecturers

\begin{tabular}{lrrrr}
\hline & $\begin{array}{c}\text { Scale Mean if } \\
\text { Item Deleted }\end{array}$ & $\begin{array}{c}\text { Scale Variance if } \\
\text { Item Deleted }\end{array}$ & $\begin{array}{c}\text { Corrected } \\
\text { Item-Total } \\
\text { Correlation }\end{array}$ & $\begin{array}{c}\text { Cronbach's } \\
\text { Alpha if Item } \\
\text { Deleted }\end{array}$ \\
\hline NLGD1 & 25.8772 & 5.601 & .493 & .631 \\
NLGD2 & 25.5965 & 6.319 & .370 & .666 \\
NLGD3 & 25.9509 & 5.455 & .491 & .631 \\
NLGD4 & 26.0175 & 5.503 & .420 & .657 \\
NLGD5 & 25.3158 & 6.689 & .339 & .674 \\
NLGD6 & 25.2667 & 6.696 & .383 & .666 \\
NLGD7 & 25.3649 & 6.726 & .340 & .674 \\
\hline
\end{tabular}

Source: Results from analyzing the survey data

It can be concluded from practical surveys that the assessment of all 7 mentioned criteria must be done in order to fully evaluate the teaching competence of lecturers.

Factors affecting the teaching competence of lecturer in agricultural colleges. The quantitative data collected from surveys using descriptive statistics presents the following factors affecting the teaching competence of lecturers:

Gender. Random surveying conducted at 12 colleges belonging to the Ministry of Agriculture and Rural Development shows that there are 119 males out of 285 people (accounting for $41.8 \%$ ), and 166 females out of 285 (58.2\%). Parameter testing method on Independent sample T-test was used in order to evaluate and test whether or not there is a difference in assessing the criteria on teaching competence between male and female lecturers.

Upon testing Levene Test with $\mathrm{F}=.241$ and equivalent significance level Sig. $=0.624>0.05$ by using parameter testing, it can be confirmed that the variance is homogeneous. T-test value of the equal variances assumed shows that Sig. $=0.668>0.05$, thereby affirming that there is no difference in assessing the criteria between teaching competence of male and female lecturers (Appendix B2). This suits the research outcomes of Pratap Singh Rana and Mr.Shakti Singh Rana, 2009.

Age group. Results of the random surveys on age group show that research subjects from 25 to 35 years old, and from 36 to 45 years old account for $79.7 \%$ ( 227 out of 285 people), as in Table 12 . This suits the reality about age group of research colleges. Since these colleges were established or upgraded within the recent 20 years, their lecturers are quite young $(\mathrm{M}=2.7)$.

Table 12. Age group of research subjects

\begin{tabular}{llrrrr}
\hline & & Frequency & Percent & Valid Percent & \multicolumn{2}{c}{ Cumulative } \\
\hline Valid & $<25$ & 5 & 1.8 & 1.8 & 1.8 \\
& $25-35$ & 141 & 49.5 & 49.5 & 51.2 \\
& $36-45$ & 86 & 30.2 & 30.2 & 81.4 \\
& $46-55$ & 41 & 14.4 & 14.4 & 95.8 \\
& $>56$ & 12 & 4.2 & 4.2 & 100.0 \\
& Total & 285 & 100.0 & 100.0 & \\
\hline
\end{tabular}

Source: Results from analyzing the survey data

Working time in teaching. Results from random surveys on working time in teaching show that with $\mathrm{M}=2.33$, the quantity of lecturers being studied mostly lies in the 2 groups: from 5 to 15 years of teach, and from 16 to 25 years of teaching, accounting for $76.8 \%$ (219 out of 285 people), as illustrated in Table 13 . This not only suits the result on age 
group, but it also suggests that the majority of lecturers in current colleges were graduates from many universities being recruited after graduation without any working experience in other enterprises.

Table 13. Working time in teaching of research subject

\begin{tabular}{llrrrr}
\hline & & & & \multicolumn{2}{c}{ Cumulative } \\
& & Frequency & Percent & Valid Percent & \multicolumn{1}{c}{ Percent } \\
\hline Valid & $<5$ years & 30 & 10.5 & 10.5 & 10.5 \\
& 5 - 15 years & 168 & 58.9 & 58.9 & 69.5 \\
& 16 - 25 years & 51 & 17.9 & 17.9 & 87.4 \\
& 26 - 35 years & 34 & 11.9 & 11.9 & 99.3 \\
& $>36$ years & 2 & .7 & .7 & 100.0 \\
& Total & 285 & 100.0 & 100.0 & \\
\hline
\end{tabular}

Source: Results from analyzing the survey data

ANOVA method is applied to test whether there is a difference in assessing the teaching competence of lecturers in terms of working time teaching.

In ANOVA test, since $\mathrm{F}=40.045$ with sig. $=0.000<0.05$, it can be affirmed that there is a difference in assessing the teaching competence of lecturers regarding to total working time in teaching. Specifically, it suggests by using Post Hoc test and Bonferroni statistics that there is difference in the teaching competence of lecturers towards working time in teaching.

Lecturers with working time in teaching from 5 to 15 years are able to better assess the criteria on teaching competence than lecturers with 5 years lower in years of teaching, provided that the average variance is $I-J=0.58316$. Similarly, lecturers with working time in teaching from 16 to 25 years are able to assess the criteria on teaching competence than lecturers with 5 years lower in years of teaching, provided that the average variance is $\mathrm{I}-\mathrm{J}=0.71877$; lecturers with 26 to 35 years of teaching differ those who have 5 years lower by $\mathrm{I}-\mathrm{J}=0.94986$, as compared to lecturers with 5 to 15 years of teaching by $\mathrm{I}-\mathrm{J}=0.3667$, and to lecturers with 16 to 25 years of teaching by $\mathrm{I}-\mathrm{J}=0.23109$. As such, lecturers with working time of over 36 years differ those who have 5 years lower, from 5 to 15 years, $16-25,26-35$, by I - J equal to $1.32381,0.70465,0.60504$ và 0.37395 , respectively.

It can be asserted from the above group analysis that in general, lecturers with longer working time in teaching have higher ability in feeling and assessing the teaching competence. Generally speaking, this perspective is completely reasonable towards the reality of teaching profession in that lecturers with more years of experience in teaching tend to offer help to younger lecturers in developing their teaching competence.

Highest educational qualification. Results from random surveys on professional qualification of research subjects present an average value $\mathrm{M}=2.6351$, meaning that the subjects focus mainly on the qualification of Engineering/BSc. And MSc. Particularly, as demonstrated in Table 20, the qualification of engineering/BSc. makes up for $28.8 \%(82 / 285$ lecturers), MSc. $64.2 \%$ (183/285 lecturers), and especially PhD. holds $2.1 \%$ (6/285 lecturers). It can be seen that the collected samples show high quality in professional qualification of research subjects.

Table 14. The professional qualification of research subjects

\begin{tabular}{llrrrr}
\hline & & & & \multicolumn{2}{c}{ Cumulative } \\
& & Frequency & \multicolumn{1}{c}{ Percent } & Valid Percent & Percent \\
\hline Valid & Vocational colleges & 14 & 4.9 & 4.9 & 4.9 \\
& Engineering/BSc. & 82 & 28.8 & 28.8 & 33.7 \\
MSc. & 183 & 64.2 & 64.2 & 97.9 \\
PhD. & 6 & 2.1 & 2.1 & 100.0 \\
Total & 285 & 100.0 & 100.0 & \\
\hline
\end{tabular}

Source: Results from analyzing the survey data 
Relevant training attended. As can be seen from Table 14, the majority of research subjects (279/285 people, 97.9\%) attended the professional training couse. This suits the reality in many colleges where graduates must attend these training classes at Pedagogy institutions before applying for lecturer position.

Table 15. Relevant training attended by research subjects

\begin{tabular}{llrrrr}
\hline & Frequency & Percent & Valid Percent & \multicolumn{2}{c}{$\begin{array}{c}\text { Cumulative } \\
\text { Percent }\end{array}$} \\
\hline Valid & $\begin{array}{l}\text { Attended relevant } \\
\text { training }\end{array}$ & 279 & 97.9 & 97.9 & 97.9 \\
& $\begin{array}{l}\text { Have not attended } \\
\text { relevant training }\end{array}$ & 6 & 2.1 & 2.1 & 100.0 \\
& Total & 285 & 100.0 & 100.0 & \\
\hline
\end{tabular}

Source: Results from analyzing the survey data

Determining the relationship between the working environment parameters and the teaching competence of lecturer in agricultural colleges in Vietnam.

Analysis model. Although the research model remained unchanged after the scale was tested the independent variables presented some changes, with a decrease in various observation variables in particular. As such, the theoretical model must be reasonably adjusted in order to ensure further model and research hypothesis testing.

The research model was adjusted with 6 factors affecting the teaching competence of lecturers equivalent to 7 assumptions as follows:

H1. There is the significant effect of working conditions factors on development of teaching competence.

$\mathrm{H} 2$. There is the significant effect of lecturer's relationships factors on development of teaching competence.

H3. There is the significant effect of student factors on development of teaching competence.

H4. There is the significant effect of study and internship opportunities factors on development of teaching competence.

H5. There is the significant effect of work pressure and managing environment factors on development of teaching competence.

H6. There is the significant effect of financial factors on development of teaching competence.

H7. There is the relationship between the working environmental factors and development of teaching competence for agriculture lecture at college in Vietnam. 


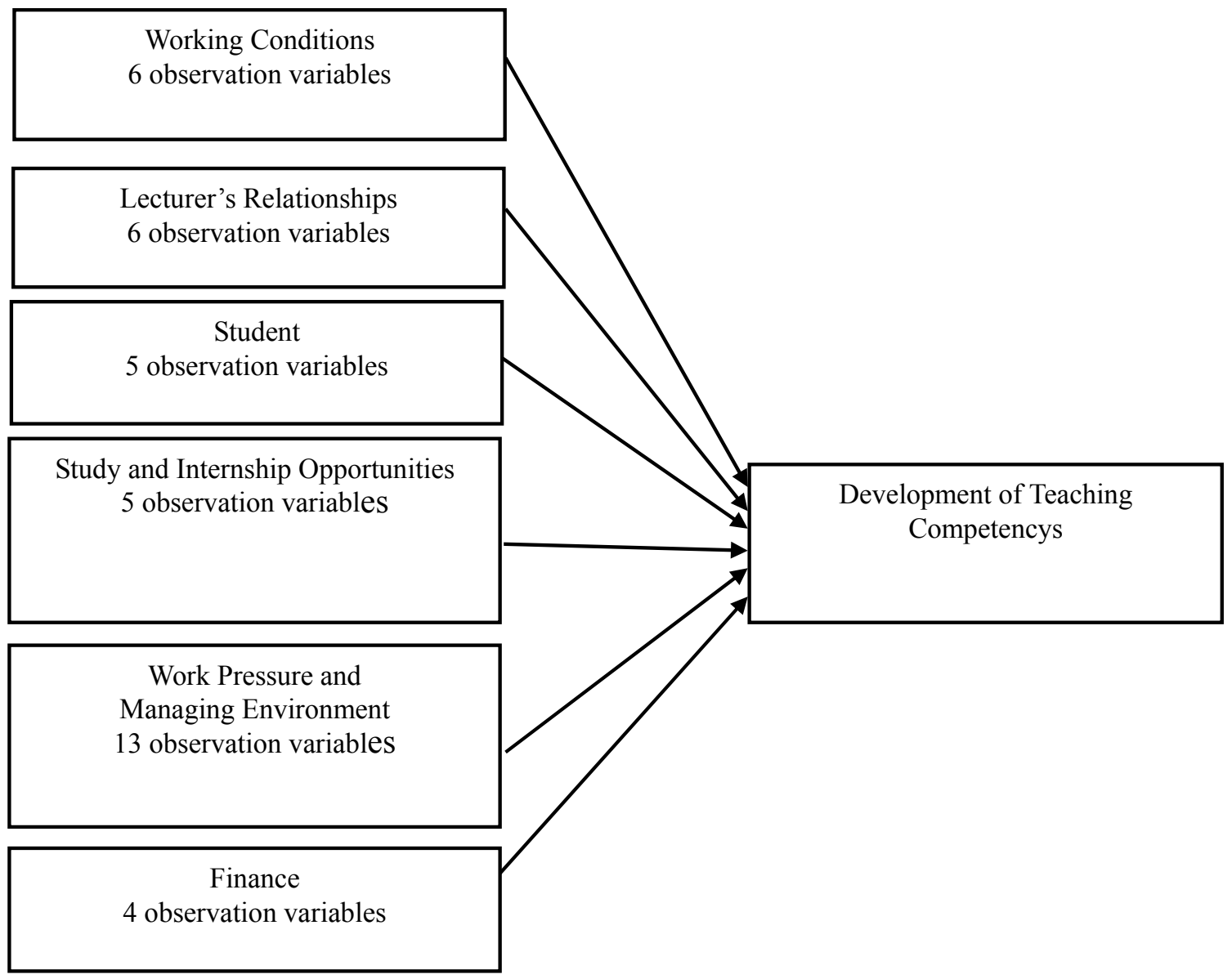

Figure 4. The adjusted research model

The regression analysis model describes the form of the relationship, hence enabling a projection of the level of independent variables once the value of these variables are known.

With the initial assumption for the theoretical model, the regression equation has the following formular:

$$
\mathrm{NLGD}=\beta_{0}+\beta_{1} * \mathrm{DKLV}+\beta_{2} * \mathrm{HTTT}+\beta_{3} * \mathrm{CV}+\beta_{4} * \mathrm{MQH}+\beta_{5} * \mathrm{SV}+\beta_{6} * \mathrm{TC}
$$

Among which:

NLGD means Teaching competence

DKLV, $\beta_{1}$ are the value and regression coefficient of the component Working conditions.

HTTT, $\beta_{2}$ are the value and regression coefficient of the component Study and internship opportunities for advancement and development.

$\mathrm{CV}, \beta_{3}$ are the value and regression coefficient of the component Work Pressure and managing environment.

$\mathrm{MQH}, \beta_{4}$ are the value and regression coefficient of the component Lecturer's relationship.

$\mathrm{SV}, \beta_{5}$ are the value and regression coefficient of the component Student.

$\mathrm{TC}, \beta_{6}$ are the value and regression coefficient of the component Finance.

$\beta_{0}$ is the value of regression coefficient

\section{Testing the suitability of research model}

After testing the scale, 6 independent variables were put to scale testing. The value of each independent variable is the average value of component observation variables of that variable, Table 16. 
Table 16. The average value of independent variables

\begin{tabular}{lcrl}
\hline & Mean & \multicolumn{1}{c}{ Std. Deviation } & \multicolumn{1}{l}{ N } \\
\hline NLGD & 4.2712 & .40282 & 285 \\
DKLV & 3.7561 & .76714 & 285 \\
MQH & 3.7228 & .82577 & 285 \\
SV & 3.8119 & .66375 & 285 \\
HTTT & 3.5733 & .66681 & 285 \\
CV & 4.1490 & .41672 & 285 \\
TC & 3.8281 & .60500 & 285 \\
\hline
\end{tabular}

Source: Results from analyzing the survey data

The result of the regression analysis shall be used to test the hypotheses from $\mathrm{H} 1$ to $\mathrm{H} 7$.

Correlation analysis. Before proceeding to conduct regression analysis, the correlation coefficient Pearson was used to quantify the level of strictness of the linear relationship between the two quantitative variables. Within Pearson correlation analysis, there is no disparity between independent variables and observation variables, yet all variables are equally assessed. However, should there be any strict correlation among the variables, it is necessary to consider the multicollinearity after conducting regression analysis.

Results of the correlation analysis is summarized in Table 17 as follows:

Concerning the correlation matrix between the variables (Table 17), the variable Teaching competence and other variables share a linear correlation larger than 0 , with the lowest correlation coefficient 0.076 (the correlation relationship between Finance and Teaching competence). Data in the table 4.21 suggests that the correlation relationship between Finance and Teaching competence is not significant, since Sig $=0.099>0.05$. As such, with the level of reliability being $95 \%$, the variable Finance shall not be used to conduct regression analysis.

Table 17. Results of correlation analysis

\begin{tabular}{llrrrrrrr}
\hline & & NLGD & DKLV & \multicolumn{1}{l}{ MQH } & \multicolumn{1}{l}{ SV } & \multicolumn{1}{l}{ HTTT } & \multicolumn{1}{l}{ CV } & \multicolumn{1}{c}{ TC } \\
\hline Pearson & NLGD & 1.000 & .687 & .667 & .216 & .372 & .204 & .076 \\
Correlation & DKLV & .687 & 1.000 & .878 & .071 & .210 & .018 & -.073 \\
& MQH & .667 & .878 & 1.000 & .058 & .215 & .027 & -.062 \\
& SV & .216 & .071 & .058 & 1.000 & .148 & .189 & .031 \\
& HTTT & .372 & .210 & .215 & .148 & 1.000 & -.002 & .024 \\
& CV & .204 & .018 & .027 & .189 & -.002 & 1.000 & .345 \\
& TC & .076 & -.073 & -.062 & .031 & .024 & .345 & 1.000 \\
\hline Sig. (1-tailed) & NLGD &. & .000 & .000 & .000 & .000 & .000 & .099 \\
& DKLV & .000 &. & .000 & .116 & .000 & .379 & .111 \\
& MQH & .000 & .000 &. & .166 & .000 & .328 & .147 \\
& SV & .000 & .116 & .166 &. & .006 & .001 & .299 \\
& HTTT & .000 & .000 & .000 & .006 &. & .489 & .346 \\
& CV & .000 & .379 & .328 & .001 & .489 &. & .000 \\
& TC & .099 & .111 & .147 & .299 & .346 & .000 & \\
& TC
\end{tabular}

Source: Results from analyzing the survey data 
Regression analysis. The multiple regression analysis used herein is Stepwise method. Results of the multiple regression analysis are as follows:

Conducting 5 steps (Model) produces the results illustrated in Table 18.

According to Le Van Huy, Truong Tran Tram Anh (2012), and Hair, J. F., Black, W. C., Babin, B. J., \& Anderson, R. $E(2009)$, if $=0.5 \leq R^{2}<0.7$, the relationship between independent variables and observation variables is strict. Results of the multiple linear regression model with $\mathrm{R}^{2}=0.586>0.5$ affirms that the linear regression model constructed was appropriate to the research data collected. In other words, the components DKLV, HTTT, CV, MQH and SV are able to explain $58.6 \%$ of the teaching competence of lecturers.

Table 18. Model Summary ${ }^{\mathrm{f}}$

\begin{tabular}{lcrrrr}
\hline Model & R & R Square & $\begin{array}{c}\text { Adjusted R } \\
\text { Square }\end{array}$ & $\begin{array}{c}\text { Std. Error of the } \\
\text { Estimate }\end{array}$ & Durbin-Watson \\
\hline 1 & $.687^{\mathrm{a}}$ & .471 & .469 & .29340 & \\
2 & $.725^{\mathrm{b}}$ & .525 & .522 & .27847 & \\
3 & $.750^{\mathrm{c}}$ & .562 & .558 & .26787 & 1.689 \\
4 & $.759^{\mathrm{d}}$ & .575 & .569 & .26435 & \\
5 & $.766^{\mathrm{e}}$ & .586 & .579 & .26140 & \\
\hline a. Predictors: (Constant), DKLV & & & \\
b. Predictors: (Constant), DKLV, HTTT \\
c. Predictors: (Constant), DKLV, HTTT, CV \\
d. Predictors: (Constant), DKLV, HTTT, CV, MQH \\
e. Predictors: (Constant), DKLV, HTTT, CV, MQH, SV \\
f. Dependent Variable: NLGD
\end{tabular}

The results of ANOVA presents the statistical significance $\mathrm{F}=79.084$ and sig. $=.000<.05$, meaning the multiple linear regression model is suitable with the data set, or the independent variables have linear relationship with the observation variables. Therefore, this model can be used.

Table 19. ANOVA results

\begin{tabular}{|c|c|c|c|c|c|c|}
\hline Model & & Sum of Squares & $\mathrm{df}$ & Mean Square & $\mathrm{F}$ & Sig. \\
\hline \multirow[t]{3}{*}{5} & Regression & 27.019 & 5 & 5.404 & 79.084 & $.000^{\mathrm{e}}$ \\
\hline & Residual & 19.064 & 279 & .068 & & \\
\hline & Total & 46.083 & 284 & & & \\
\hline \multicolumn{7}{|c|}{ e. Predictors: (Constant), DKLV, HTTT, CV, MQH, SV } \\
\hline \multicolumn{7}{|c|}{ f. Dependent Variable: NLGD } \\
\hline
\end{tabular}

Source: Results from analyzing the survey data

Given the significance level of $5 \%$ for ordinary research, if sig. $<0.05$, it can be concluded that all the independent variables affect observation variables. Results of the regression coefficient analysis show that Sig. level of 5 independent variables within the model is all smaller than 0.05 , which means these variables are significant within the model, Table 20. 
Table 20. Coefficients ${ }^{\mathrm{a}}$

\begin{tabular}{|c|c|c|c|c|c|c|c|c|}
\hline \multirow{2}{*}{\multicolumn{2}{|c|}{ Model }} & \multicolumn{2}{|c|}{$\begin{array}{c}\text { Unstandardized } \\
\text { Coefficients }\end{array}$} & \multirow{2}{*}{$\begin{array}{l}\text { Standardized } \\
\text { Coefficients } \\
\text { Beta }\end{array}$} & \multirow[b]{2}{*}{$\mathrm{t}$} & \multirow[b]{2}{*}{ Sig. } & \multicolumn{2}{|c|}{$\begin{array}{c}\text { Collinearity } \\
\text { Statistics } \\
\end{array}$} \\
\hline & & B & Std. Error & & & & Tolerance & VIF \\
\hline \multirow[t]{6}{*}{$\overline{5}$} & (Constant) & 1.612 & .191 & & 8.443 & .000 & & \\
\hline & DKLV & .219 & .042 & .416 & 5.156 & .000 & .227 & 4.396 \\
\hline & HTTT & .131 & .024 & .216 & 5.420 & .000 & .932 & 1.072 \\
\hline & $\mathrm{CV}$ & .164 & .038 & .169 & 4.317 & .000 & .963 & 1.039 \\
\hline & MQH & .119 & .039 & .244 & 3.015 & .003 & .227 & 4.403 \\
\hline & SV & .065 & .024 & .108 & 2.714 & .007 & .940 & 1.064 \\
\hline
\end{tabular}

a. Dependent Variable: NLGD

Source: Results from analyzing the survey data

Regression equation. After conducting the multiple linear regression model, the results collected show that the relationship between independent and observation variables is demonstrated in the following equation:

$$
\begin{aligned}
& N L G D=1.612+0.219 * D K L V+0.164 * C V+0.131 * H T T T+0.119 * M Q H+ \\
& +0.065 * S V
\end{aligned}
$$

In the above regression equation, all Beta $>0$, meaning the independent variables positively affect the teaching competence of lecturers.

The factor "Working conditions" has the largest regression coefficient of 0.219 . The significance of Beta is explained as: if the influence of other factors on the teaching competence of lecturers remains unchanged, 1-unit increase of the factor Working conditions shall affect the teaching competence of lecturers by increasing it to 0.219 more unit. According to the results of Crobach's Alpha testing, the factor Working conditions are measured by the following 6 criteria: i) Working equipment for lecturers (working room, desk/chair, computer, stationery, labor protection; ii) Assisting devices for teaching (classroom and classroom equipment (table, chair, fan, board...), projector, function room), iii) Library with plenty of books, professional materials, reference materials and other materials (hard and soft copies); iv) Information system (internet connection, the college's website), v) Facilities for activities in Culture/Art, $\mathrm{PE} /$ sports, recreational activities); vi) Teaching facilities (workshops/farm for practice, lab, model and other tools)

The factor "Working pressure and managing environment" has a regression coefficient of 0,164 . This factor is of prime importance to the development of the teaching competence of lecturers. The significance of Beta is explained as: if the influence of other factors on the teaching competence of lecturers remains unchanged, 1-unit increase of the factor Working pressure and managing environment shall affect the teaching competence of lecturers by increasing it to 0.164 more unit. According to the results of Crobach's Alpha testing, the factor Working pressure and managing environment is measured by the following 13 criteria: i) The objectives of the subjects taken by the lecturers; ii) The subject's syllabus is highly vocational and practical; iii) The subject's syllabus is suitable with the international integration trend; iv) Extra-curriculum activities for students; v) The allocation of annual teaching hours of lecturers; vi) Complete rules and stipulations towards teaching; vii) Lecturers are entitled to participate in building plans for the college; viii) Lecturers are fairly assessed and recognized their performance; ix) Lecturers are allowed to take on constant subjects; $\mathrm{x}$ ) The subtle and tactful discipline handling from management level; $\mathrm{xi}$ ) The care and support from management level towards personal issues; xii) The policy of the college to attract and use talents; xiii) The college's position and tradition.

The factor "Study and internship opportunities for advancement and development" has the third largest regression coefficient of 0.131. The significance of Beta is explained as: if the influence of other factors on the teaching competence of lecturers remains unchanged, 1-unit increase of the factor Study and internship opportunities for advancement and development shall affect the teaching competence of lecturers by increasing it to 0.131 more unit. According to the results of Crobach's Alpha testing, the factor Study and internship opportunities for advancement and development is measured by the following 5 criteria: i) The college's policy to encourage studying for advancement; ii) Lecturers are facilitated to attend training courses on teaching methodology; iii) Lecturers are facilitated to attend thematic seminars to update professional information (both inside and outside the country); iv) Lecturers are facilitated to take part in fieldtrips/internships at many manufacturing firms/businesses according to their specialization; v) The equality in promotion opportunities.

The factor "Lecturer's relationship" has a regression coefficient of 0.119. The significance of Beta is explained as: if the influence of other factors on the teaching competence of lecturers remains unchanged, 1-unit increase of the factor 
Lecturer's relationship shall affect the teaching competence of lecturers by increasing it to 0.119 more unit. According to the results of Crobach's Alpha testing, the factor Lecturer's relationship is measured by the following 6 criteria: i) The sharing and help from other members of department/faculty; ii) The enthusiastic instruction of experienced lecturers from within the faculty; iii) The role of managing officers (subject, faculty, function department); iv) Participating in political - social organizations in the college; v) Lecturers are allowed to work in the college's workshops/farms (after class); vi) Other lecturers and officers in the college.

The factor "Students" has the fifth largest regression coefficient of 0.0655. The significance of Beta is explained as: if the influence of other factors on the teaching competence of lecturers remains unchanged, 1-unit increase of the factor Students shall affect the teaching competence of lecturers by increasing it to 0.0655 more unit. According to the results of Crobach's Alpha testing, the factor Students is measured by the following 5 criteria: i) The interaction, self-awareness and positiveness of students; ii) The level of passiveness of students; iii) The level of interest towards the subjects of students; iv) Study activities of students; v) The level of responsiveness of students (answering the questions, doing homework...)

It can be concluded from the above analysis that accepted hypotheses of the model include $\mathrm{H} 1, \mathrm{H} 2, \mathrm{H} 3, \mathrm{H} 4, \mathrm{H} 5$, among which:

H1. There is the positvive effect of working conditions factors on development of teaching competence.

$\mathrm{H} 2$. There is the positvive effect of lecturer's relationships factors on development of teaching competence.

H3. There is the positvive effect of student factors on development of teaching competence.

$\mathrm{H} 4$. There is the positvive effect of study and internship opportunities factors on development of teaching competence.

H5. There is the positvive effect of work pressure and managing environment factors on development of teaching competence.

\section{Conclusions}

According to Theo Hoang Trong, Chu Nguyen Mong Ngoc (2008) và Nguyen Dinh Tho (2012), the regression equation (1) is called unstandardized regression equation, in which all regression coefficients are yet to be standardized. This means all of the variables keep their original units. Unstandardized regression equation is more mathematically than economically significant, which reflects the change in the dependent variables when each independent variable changes but the remaining independent variables remain unchanged.

In the standardized regression equation, all variables are specified to the same unit. Standardized regression equation is more economically than mathematically significant. Based on the regression equation, economists are able to identify what factor is the most important (the larger regression coefficient is the more important), what factor is less important in order to invest time, effort and finance more reasonably. A larger regression coefficient needs more concern and investment since it affects more greatly the dependent variables.

By using the standardized regression coefficient as in Table 32, the equation (1) is standardized and re-arranged in descending order of regression coefficient as follows:

$$
\begin{aligned}
& N L G D=0.416 * D K L V+0.244 * M Q H+0.216 * H T T T+0.169 * C V+ \\
& +0.108 * S V
\end{aligned}
$$

Based on the standardized regression equation (2) and results from Table 4.23, it can be concluded about the research model that:

Hypothesis H1: Working conditions positively affected the development of teaching competence of lecturers. In the standardized regression equation, this factor has the largest standardized regression coefficient $(0.416, \mathrm{Sig} .=.000)$. This means that among the factors affecting the teaching competence of lecturers, the factor Working conditions has the largest level of covariance impact. As such, if financially favored, colleges should prioritize the investment into enhancing the working conditions for lecturers, such as: Teaching equipment, assisting devices for teaching, library, information system... in order to facilitate lecturers to develop their teaching competence with the best working conditions.

Hypothesis H2: Lecturer's relationship positively influenced the development of teaching competence of lecturers. In the standardized regression equation, this factor carries the second largest standardized regression coefficient $(0.244$, Sig. $=.003)$. Lecturer's relationship is defined as a cultural-psychological environment or the working atmosphere surrounding lecturers. Although the standardized regression coefficient of this factor is not as large as of the factor Working conditions (physical working environment), it is still the largest in terms of the cultural-psychological environment. Specifically promote the role of specialized group in enhancing and developing the teaching competence of young lecturers. Apart from appointing experienced lecturers to directly train young lecturers, the specialized group 
needs to organize more professional activities (class observation, seminar, thematic talk, professional discussion...), Le Cong Triem, Nguyen Duc Vu, 2013.

Hypothesis H3: The factor Study and internship opportunity for advancement and development positively affected the development of teaching competence of lecturers. In the standardized regression equation, this factor presents the third largest standardized regression coefficient $(0.216, \mathrm{Sig} .=.000)$. Studying and internship opportunity for advancement and development is defined as part of the cultural-psychological environment of the colleges. Particularly, this factor carries the second most powerful impact on the development of teaching competence of lecturers.

Hypothesis H4: The factor of Work pressure and managing environment positively influenced the development of teaching competence of lecturers. In the standardized regression equation, this factor presents a standardized regression coefficient of 0.216 with Sig. $=.000$. Work pressure and managing environment is defined as part of the cultural-psychological environment of the colleges which greatly impacts the development of teaching competence of lecturers. This outcome is completely suitable with previous researches presented in Chapter II: The model of 10 factors on motivating employee, developed by Kenneth A. Kovach 1987; Mohammad Nadeem et al., 2011, concluded that over workload, bad conditions of school building, lack of library facility, lack of teaching and learning material, status of teacher, lack of co-operation, working relations with staff and head teacher, working environment, are the factors which affect the female teachers' performance negatively; Markey and Shulruf, 2008, pointed out managers of public universities encourage teamwork and teams succeed when there is cooperation, collaboration and trust amongst members and stakeholders; James R.K.Kagaari, John C.Munene, Joseph M.Ntayi, 2013, indicated that management of public universities was able to support and build trust amongst employees.

Hypothesis H5: The factor of Student is part of the cultural-psychological environment. Considering its impact and responsiveness, students are subjects to the process of conducting teaching competence of lecturers. In the standardized regression equation, this factor presents a standardized regression coefficient of $0.108, \mathrm{Sig} .=.007$. Therefore, the factor Student positively impacts the development of teaching competence of lecturers. This is completely suitable with previous researches presented in Chapter II: Nguyen Van Luot, 2012, suggested that lecturers' motivation and devotion are affected by students, in which the interest and enthusiasm of students towards the subject... become the motivation for lecturers to overcome difficulties and challenges, and help them to strive for better teaching; Richard W. Riley, Sharon P. Robinson et al., 1996, pointed out the student readiness to learn: classes full of students ready and eager to learn make a teacher's job much easier and more enjoyable...

As such, colleges need to improve the factor Student to facilitate lecturers to develop their teaching competence.

Hypothesis H6. Although there is a significant effect of financial factors on the development of teaching competence, this hypothesis is yet to be accepted. It can be explained as follows: Considering the quantitative aspect, the factor Finance presents a Cronbach's Alpha of $0.721>0.6$ with $\mathrm{M}=3.281$, and the total variance correlation coefficients all larger than 0.3 , Table 27. This factor is measured by the following 4 criteria: i) The scheme for extra income payment and rewarding of the college based on individual contributions; ii) The policy of the college to award excellent lecturers; iii) The current scheme for insurance and pension assures lecturers to focus on teaching; iv) The allowances for unemployment, difficult circumstances, health check-up, travel and sick leave, holiday, funeral, wedding,...) motivate lecturers in teaching.

As such, 5 out of 6 hypotheses (accounting for 83.3\%) are accepted in the experimental research. In other words, 5 out of 6 factors of the working environment affected the development of teaching competence of lecturers, hence affirming that hypothesis $\mathrm{H} 7$ is accepted, meaning there is the positvivere lationship between the working environmental factors and development of teaching competence for agriculture lecture at college in Vietnam.

The results withdrawn from data interpretation show that the assessment of teaching competence of lecturers requires a thorough evaluation of the aforementioned 7 factors. In other words, the development of teaching competence of lecturers means the improvement of these factors. The factors of working environment are listed in descending order of their influence on the development of lecturer's teaching competence as follows: i) Working conditions; ii) Lecturer's relationships; iii) Study and promotion opportunities of lecturers; iv) Working pressure and managing environment; v) Students. Within these factors, the factor working conditions is dependent on financial investment, whereas others depend less on financial investment but more on time investment and support from the leaders and staff of lecturers to improve the cultural-psychological environment; at the same time it is necessary for colleges to build reasonable schemes and policies towards lecturers.

Results of this research are important and reliable scientific materials, on which colleges can apply to enhance the working environment of lecturers, contributing to helping them develop their teaching competence and improving the quality of teaching. This research also serves as the scientific foundation for future research in relevant fields.

\section{References}


Bui Huy Khien. (2013). Environment and working environment in the public sector. Public Management, Chapter 5, Public Administration Publishing House.

Dauda Abdulsalam, \& Mohammed Abubakar Mawoli. (2012). Motivation and Job Performance of Academic Staff. International Journal of Business and Manegement, 7(14).

Franz E. Weinert. (1999). Concepts of Competence. Max Planck Institute for Psychological Research, Munich, Germany.

Geijsel, F., Sleegers, P., Stoel, R., \& Krüger, M. (2009). The Effect of Lecturer Psychological, School Organizational and Leadership Factors on Lecturers' Professional Learning in Dutch Schools. The Elementary School Journal, 109(4), 406-427.

General Assembly Vietnam Agriculture and Rural Development. (2015). ARD Yearbook Vietnam. Dong tay Media Group.

Gupta. K.N. (2009). Professional Ethics, Values and Competency in Lecturer Education. International Journal of Education and Allied Sciences, 1(1), 47-50.

Hagger, H., \& McIntyre, D. (2006). Learning teaching from lecturers. Realizing the potential of school-based lecturer education. Maidenhead: Open University Press.

Hair, J. F., Jr., R. E. Anderson, R. L. Tatham, \& W. C. Black. (1998). Multivariate Data Analysis with Readings (5th ed.). Englewood Cliffs, NJ: Prentice Hall.

Herzbeg, F. (1991). One more time. How do you motivate employees?. Harvard Business Review Classics, $13-62$.

Koster, B., \& Dengerink, J. J. (2008). Professional standards for lecturer educators: how to deal with complexity, ownership and function. Experiences from the Netherlands. European Journal of Lecturer Education, 31(2), 135-149.

Krueger RA. (1998). Focus Group: ModeratingFocus Groups. Thousand Oaks CA: Sage.

Laurie Lewis, Basmat Parsad, et al. (1999, January). Lecturer Quality: A Report on The Preparation and Qualifications of Public School Lecturers. U.S. Department of Education Institute of Education Sciences, National Center for Education Statistics, NCES: 1999080.

Le Cong Triem, \& Nguyen Duc Vu. (2013). Some solutions for competence development of education and scientific research competence for young lecturers. Scientific journal of HCMC University of Education, (42).

Le Van Huy, \& Truong Tran Tram Anh. (2012). Research Methods in Business. Finance Publishing House.

Markey, R., \& Shulruf, B. (2008). Effects of workplace practices on profitability: Evidence from New Zealand. Paper presented at 6th Regional Congress for the Americas of the International Industrial Relations Association, Buenos Aires.

Neal Van Alfen, J. Scott Angle, H. Ray Gamble, Andrew G. Hashimoto, Jaw-Kai Wang, Lynne McNamara, \& Nguyen Thi Thanh Phuong. (2007). Observations on the current state of education in the sector of Agricultural Sciences in Vietnam. Report of Survey Regiment of the National Academy of the United States presented to the Vietnam Education Foundation.

Nguyen Dinh Luan. (2013). Three important factors improve the quality of training. Retrieved from www.gdtd.vn

Nguyen Dinh Tho. (2012). Scientific research methods in business. Labor -SocialPublishing House.

Nguyen Huu Lam. (2009). Competence development for lecturers to improve the quality of education and training in universities and colleges in the conditions of globalization and information explosion. Centre for Research \& Development Management - HCM City University of Economics.

Quy Long, \& Kim Thu. (2009). Vietnamese dictionary. Labor Publishing House.

Rama, M. (1979). Factorial Structure of Teaching Competencies among Secondary School Lecturers. Unpublished Doctoral Dissertation, M.S.University Baroda.

Richard W. Riley, \& Sharon P. Robinson. (1996). Teacher working conditions. U.S. Department of Education Institute of Education Sciences, National Center for Education Statistics, NCES 97-371.

Roberts. (2005). Computer-Supported Collaborative Learning in Higher Education. London, Idea Group Publication.

Singh, P., \& Manser, P. (2002). Collegiality in education: a case study. South African Journal of Education, 22(1), 56-64.

Tabachnick, B.G., \& Fidell, L.S. (2007). Using Multivariate Statistics (5th ed.). Boston: Pearson Education.

Van Dalen, D.B. (1993). Understanding Education Research. USA; Me Graw: Hill Book Co. 